\title{
THE PARTICIPATION OF BONE IN TOTAL BODY SODIUM METABOLISM IN THE RAT ${ }^{1}$
}

\author{
BY WILLIAM H. BERGSTROM 2 \\ (From the Department of Pediatrics, New York State University College of Medicine, \\ Syracuse, $N . Y$.)
}

(Submitted for publication November 15, 1954 ; accepted March 9, 1955)

Sixty years ago Gabriel demonstrated the presence of substantial amounts of sodium in the chloride-free residue of bone which had been extracted with alkaline glycol solutions (1). In 1936, Harrison, Darrow, and Yannet (2) defined "extra" bone sodium as that present in excess of the amount predictable from chloride content and suggested that at least 25 per cent of the total body sodium content might be bound chemically to bone salt. Subsequently, Kaltreider, Meneely, Allen, and Bale (3), Forbes and Perley (4), Stern, Cole, Bass, and Overman (5), and Edelman, James, Baden, and Moore (6) have shown that 30 to 40 per cent of bone sodium is exchangeable with circulating radiosodium within 24 hours. These workers have confirmed the earlier impressions of Harrison, Darrow, and Yannet by finding approximately one-third of total body sodium to be in the skeleton.

Reduction of bone sodium during acute acidosis has been demonstrated in dogs by Nichols and Nichols (7) and in rats by Bergstrom and Wallace (8). The former found an average decrease of $18.6 \mathrm{mEq}$. of sodium per kilogram of wet fat-free bone in dogs after four hours of sodium depletion by means of hemodialysis. Rats depleted of sodium and made acidotic by intraperitoneal dialysis against ammonium chloride solutions lost $42 \mathrm{mEq}$. of sodium per kilogram of wet bone within 48 hours. This represents 28 per cent of the total extra bone sodium and corresponds closely in magnitude to the fraction shown previously to be exchangeable with circulating radioisotope.

Darrow, Schwartz, Iannucci, and Coville (9), Cotlove, Holliday, Schwartz, and Wallace (10), and others have indicated that intracellular sodium may undergo wide fluctuations around its normal

1 This investigation was supported in part by a grant (A-361) from the National Institute of Arthritis and Metabolic Diseases of the National Institutes of Health, Public Health Service.

2 Markle Scholar in Medical Science. value of 9 to $10 \mathrm{mEq}$. per liter of muscle cell water. Concentrations of $1 \mathrm{mEq}$. per liter in acidosis and of $22 \mathrm{mEq}$. per liter in alkalosis are reported. Apparently sodium exists in the body in at least three phases : extracellular fluid, intracellular fluid, and bone salt. All participate in sodium metabolism, though bone sodium may consist of accessible and inaccessible fractions.

The work to be reported here concerns the following: 1) What proportion of total sodium loss in acute acidosis and sodium depletion is borne by bone sodium? 2) Is bone sodium content diminished by acidosis without large loss of sodium, i.e., can changes in body fluid $\mathrm{pH}$ affect the pattern of bone electrolyte? 3) Can the fraction of bone sodium removed be increased by repeated depletion procedures? 4) During recovery from acidosis, what proportion of the sodium retained is deposited in the skeleton?

\section{EXPERIMENTAL PROCEDURE}

Six groups of adult male albino rats were used. Group 1 (20 animals). Control rats were maintained on a diet of dog chow and water ad lib. At the time of sacrifice samples of bone and blood were taken for analysis as described below. Fourteen carcasses were then dried at $105^{\circ} \mathrm{C}$., defatted, and analyzed for sodium, calcium, and chloride.

Group 2 (7 animals). These were depleted of sodium and made acidotic by transperitoneal dialysis against ammonium chloride. Each rat received intraperitoneally 10 per cent of its body weight of a solution containing 90 millimoles of ammonium chloride and 50 grams of glucose per liter. After a four-hour equilibration period the peritoneal fluid was withdrawn and analyzed for sodium. Approximately 25 per cent of the estimated total body sodium content is removed by this procedure (8). The animals were then allowed water but fasted for 48 hours prior to sacrifice. The total urinary output of four animals was collected during the 48-hour post-dialysis period and analyzed for sodium. The sampling procedure was that used for Group 1.

Group 3 (12 animals). After a 12-day control period on chow and water, eight animals in this group were 
given acetazoleamide (Diamox(8) ${ }^{3}$ in a concentration of $666 \mathrm{mg}$. per liter in their drinking water. The remaining four animals were continued on tap water. All were weighed daily throughout the experiment. Serum $\mathrm{pH}$ was measured in both control and experimental rats before and during treatment. After sixteen days of drug administration the rats were killed and sampled as above.

Group 4 (6 animals). These were given acetazoleamide as in Group 3. After 13 days of treatment they were subjected to dialysis as in Group 2. A 48-hour period of fasting preceded sampling. Blood and bone samples only were analyzed in this group.

Group 5 (7 animals). These were subjected to the same depletion procedure as Group 2. At the conclusion of the 48-hour fast they received $200 \mathrm{ml}$. per kilo of body weight of a solution containing $150 \mathrm{mEq}$. of $\mathrm{Na}, 100 \mathrm{mEq}$. of $\mathrm{Cl}$, and $50 \mathrm{mEq}$. of $\mathrm{HCO}_{8}^{-}$per liter. This was given intraperitoneally in two doses ten hours apart. After 24 hours of "repair" (72 hours after dialysis) the rats were killed and sampled.

Group 6 (9 animals). These were depleted as in Group 2. After the 48-hour post-dialysis period they were allowed chow and water ad lib. They were sacrificed five days later when they had regained 86 per cent of the weight lost after dialysis.

\section{CHEMICAL METHODS}

A. Serum: 1) Water was determined by the use of micropycnometers (10). 2) Sodium was measured by internal standard flame photometry (11). 3) Chloride was measured by the iodometric method of Van Slyke and Hiller (12). 4) Serum $\mathrm{pH}$ was determined at $38^{\circ} \mathrm{C}$. with the bicolor standards of Hastings and Sendroy (13).

B. Carcass: 1) The method of preparation was that of Schwartz, Cohen, and Wallace (14), except that the animals were not exsanguinated; only small samples (2 to $3 \mathrm{ml}$.) of blood were taken. 2) Total body water was measured as weight lost after drying to constant weight at $105^{\circ} \mathrm{C}$. 3) Fat was determined by extracting the dry material with several changes of a mixture of ethyl and petroleum ether and re-weighing. 4) Chloride was measured by back titration of excess silver after the dry fatfree material had been soaked for 24 hours in a measured excess of silver nitrate and dissolved and digested in nitric acid (14). 5) Calcium was precipitated as oxalate which was then titrated with permanganate. 6) Sodium was measured by internal standard flame photometry after removal of calcium by oxalate precipitation. Three successive recrystallizations of calcium oxalate were carried out in order to recover co-precipitated and adsorbed sodium ( 8 ).

C. Bone: The method of analysis has been presented in detail elsewhere (8). Samples included all of the long bones in most cases. In some instances only femora and tibiae were taken for analysis. No difference in results was seen. 1) Water was measured as weight loss

${ }^{3}$ This drug was kindly supplied by Drs. T. H. Maren and J. M. Ruegsegger of Lederle Laboratories. after drying at $105^{\circ} \mathrm{C}$. The bones were then ground to a fine powder and aliquots taken for subsequent analyses. 2) Chlorides were measured by an adaptation of Sunderman and Williams' method (15) to semi-micro quantities. 3) Sodium was determined by internal standard flame photometry on aliquots ashed and dissolved in nitric acid. Calcium separation was carried out as described above prior to flaming. 4) Calcium was titrated as oxalate with permanganate.

\section{CALCULATIONS}

The concentrations of sodium and chloride in extracellular water were calculated from measurements of serum sodium, chloride, and water using Donnan's factors $\left(\mathrm{Cl}_{\text {eew }}=1.02 \times \mathrm{Cl}_{\text {sorum HzO }} ; \mathrm{Na}_{\text {oew }}=0.95 \times \mathrm{Na}_{\text {sorum } \mathrm{H}_{20}}\right)$. Bone chloride was multiplied by the ratio $\mathrm{Na}$ ocw/Clocw to give the amount of bone sodium predictable from extracellular water content as defined by chloride. This was subtracted from total bone sodium $\left(\mathrm{Na}_{t}\right)$ to give "extra" bone sodium $\left(\mathrm{Na}_{c}\right)$ as originally defined by Harrison, Darrow, and Yannet (2). The ratio of extra bone sodium to calcium was then calculated. Total body calcium content was multiplied by the ratio $\mathrm{Na}_{\mathrm{e}} / \mathrm{Ca}$ to give the extra bone sodium content of the whole body. The assumption was made that the amount of nonskeletal calcium measured in total calcium was negligible.

The volume of distribution of extracellular sodium, $\left(\mathrm{H}_{2} \mathrm{O}_{\mathrm{Na}}\right)$, was derived by subtracting intracellular and bone sodium from total sodium content and dividing the remainder by the sodium concentration of extracellular water. Intracellular sodium was approximated by using the data of Cotlove, Holliday, Schwartz, and Wallace for muscle sodium in normal and acidotic rats (10), assuming a muscle mass equal to 40 per cent of body weight. Neglecting intracellular $\mathrm{Na}$ in tissues other than muscle introduces a source of error which makes the value for extracellular $\mathrm{Na}$ an estimate rather than a precise quantity.

The concentrations of chloride in red cell water and in collagen water differ from that in extracellular water, and the necessity of correcting the apparent chloride space for these two factors has been stated by Harrison, Darrow, and Yannet (2) and by Nichols, Nichols, Weil, and Wallace (16). According to Bernstein (17), the chloride concentration of rat erythrocyte water is 82 $\mathrm{mEq}$. per L. If blood volume is assumed to be 10 per cent of body weight, hematocrit 50 per cent, and red cell water $720 \mathrm{ml}$. per $\mathrm{Kg}$. of cells, erythrocyte chloride equals $0.100 \times .50 \times .72 \times 82=3 \mathrm{mEq}$. per $\mathrm{Kg}$. body weight. Nichols, Nichols, Weil, and Wallace (16), using the total body collagen data of Lightfoot and Coolidge (18), and analyses of tendon for water and collagen, calculated that $77 \mathrm{ml}$. of water per $\mathrm{Kg}$. of body weight is associated with collagen and elastin. In this phase they found an average chloride concentration of $129 \mathrm{mEq}$. per L., which is $12 \mathrm{mEq}$. per L. greater than that calculated for extracellular water not so associated. The correction introduced amounts to $0.077 \times 12=0.9 \mathrm{mEq}$. per $\mathrm{Kg}$. body weight. The sum of both corrections ( 3 plus $0.9=3.9$ ) 
TABLE I

Average changes following intraperitoneal dialysis (seven rats)

\begin{tabular}{|c|c|c|c|c|c|}
\hline \multicolumn{3}{|c|}{ Body Welght } & \multicolumn{3}{|c|}{ Sodium } \\
\hline Bofore & After & \multirow[t]{2}{*}{ \$ Los8 } & Orlginal & \multicolumn{2}{|c|}{ Removed } \\
\hline$\left(G_{0}\right)$ & $\left(c_{0}\right)$ & & $=x_{g} / x_{B}$ & $=\mathrm{ma} / \mathrm{K}_{\mathrm{g}}$ & 8 \\
\hline 216 & 197 & 20 & 52.8 & 11.4 & 22.6 \\
\hline
\end{tabular}

was subtracted from total chloride content before calculating the volume of distribution.

\section{RESULTS}

\section{Acute sodium depletion and acidosis}

Table I shows the average weight loss following dialysis in Group 2 and the amount of sodium removed as determined by analysis of the dialysate. Sodium withdrawn is expressed as per cent of total body content, calculated from original body weight and average normal sodium content (Table II). The total urinary sodium output during 48 hours was less than $1 \mathrm{mEq}$. per kilo of body weight per day. There was no change in serum sodium concentration or in sodium content in $\mathrm{mEq}$. per kilo of final body weight (Table II). The ratio of sodium to calcium in bone was 0.016 as compared to 0.021 in control animals (Table III).

From body composition after dialysis and per cent of weight lost it is possible to calculate the amount of sodium lost per kilogram of original body weight. Table IV shows the total loss so calculated and the contribution of each phase.
The results are shown as $\mathrm{mEq}$. per $\mathrm{Kg}$. before and after dialysis and as $\mathrm{mEq}$. per $800 \mathrm{gm}$. The latter notation indicates the loss sustained by each original $\mathrm{Kg}$. after a 20 per cent weight loss. The average total extra bone sodium content of 14 normal rats was $11.2 \mathrm{mEq}$. per $\mathrm{Kg}$. fat-free wet weight (Total calcium $=546 \mathrm{mEq}$. per $\mathrm{Kg}$.; $\mathrm{Na}_{\mathrm{c}} / \mathrm{Ca}$ ratio $=.0206$ ). In seven dialyzed rats total calcium was $633 \mathrm{mEq}$. per $\mathrm{Kg}$. and $\mathrm{Na}_{\mathrm{c}} / \mathrm{Ca}$ was .0163 . Total extra bone sodium was therefore $10.3 \mathrm{mEq}$. per $\mathrm{Kg}$. Since body weight after dialysis was $0.8 \times$ original weight (Table I) the decrease in extra bone sodium was $11.2-(10.3 \times$ $.8)=3.0 \mathrm{mEq}$. per original $\mathrm{Kg}$. This represents 28 per cent of the total sodium loss of $10.8 \mathrm{mEq}$. per $\mathrm{Kg}$.

Values for the intracellular phase were calculated from the muscle data of Cotlove, Holliday, Schwartz, and Wallace for rats subjected to an identical depletion procedure (10). These workers found that the intracellular sodium content of muscle after dialysis was $0.6 \mathrm{mEq}$. per $\mathrm{Kg}$. of muscle as compared to $6.0 \mathrm{mEq}$. per $\mathrm{Kg}$. in con-

TABLE II

Body composition in control, dialyzed, and repaired rats

\begin{tabular}{|c|c|c|c|c|c|c|c|c|}
\hline \multirow{3}{*}{ Groop (n) } & \multicolumn{2}{|l|}{$\mathbf{c}$} & \multirow{2}{*}{ 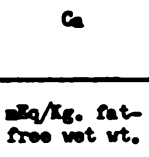 } & \multicolumn{2}{|l|}{ CI } & $\mathrm{B}_{2} \mathrm{O}_{\mathrm{m}}$ & $\mathrm{B}_{2} \mathrm{OCI}_{\mathrm{Cl}}$ & $\mathrm{B}_{2} \mathrm{O}_{2}$ \\
\hline & 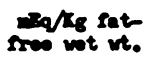 & $=$ & & $\begin{array}{l}\text { eq/7e fat } \\
\text { fres wot wt. }\end{array}$ & $=\frac{\operatorname{lag} t}{\mathrm{ECN}}$ & \multicolumn{3}{|c|}{ 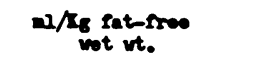 } \\
\hline & 53 & 155 & 546 & 36 & wh & 251 & 282 & 732 \\
\hline 2. (Dialsyed) (7) & 53 & 253 & 633 & 39 & 107 & 274 & 329 & 721 \\
\hline 3. (Dimex) (6) & 5 & 253 & 599 & 37 & س & - & 298 & 72 \\
\hline 5. (Ropa1r) (7) & 59 & 150 & 621 & 42 & 97 & - & 393 & 731 \\
\hline
\end{tabular}


TABLE II

Bone composition

\begin{tabular}{|c|c|c|c|c|}
\hline \multirow[t]{2}{*}{ anopen $\quad(n)$} & \multicolumn{3}{|c|}{ Ig/ts. wet voldt } & \multirow[b]{2}{*}{$m / a$} \\
\hline & thet & $\mathbf{n}_{\mathbf{0}}$ & $a$ & \\
\hline $\begin{array}{l}\text { 1. Conterl (20) } \\
\left(8 . x_{0}\right)\end{array}$ & 198 & 261 & 7900 & $\begin{array}{l}.0206 \\
(.00007)\end{array}$ \\
\hline $\begin{array}{c}\text { 2. Dialyeed } \\
\left(8 . x_{0}\right)\end{array}$ & 262 & 224 & 7600 & $\begin{array}{l}.0063 \\
(.0012)\end{array}$ \\
\hline $\begin{array}{l}\text { 3. Aoptasole (7) } \\
\text { indop }\end{array}$ & 152 & 220 & 8000 & .0150 \\
\hline 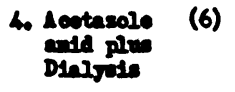 & 276 & 238 & 7900 & .0274 \\
\hline $\begin{array}{l}\text { 5. Pareateral (7) } \\
\text { Ropals } \\
\left(8, x_{0}\right)\end{array}$ & 243 & 98 & 7200 & $\begin{array}{l}.0236 \\
(.0006)\end{array}$ \\
\hline $\begin{array}{l}\text { 6. Orel sopels (9) } \\
\text { (S.5.) }\end{array}$ & 164 & 236 & $7 m 00$ & $\begin{array}{l}.0275 \\
(.0005)\end{array}$ \\
\hline
\end{tabular}

trol rats. If muscle mass is assumed to equal 40 per cent of body weight originally, intracellular sodium loss per $\mathrm{Kg}$. will equal $.4 \times(6.0-0.6)=$ $2.2 \mathrm{mEq}$. The error introduced by decrease in muscle mass during weight loss will be small since the intracellular sodium of post-dialysis muscle is minimal. The loss sustained by extracellular fluid may be estimated as total $\mathrm{Na}$ loss-(bone loss + intracellular loss).

The total loss by analysis, $10.7 \mathrm{mEq}$. per origi- nal kilogram, is 20.5 per cent of the original content, a figure which agrees well with the measured removal of 22 per cent indicated in Table $I$. Fifty-two per cent of the total loss was sustained by extracellular sodium, 28 per cent by bone sodium, and 20 per cent by intracellular sodium.

\section{Acetazoleamide treatment}

Figure 1 shows the changes in body weight, growth rate, and serum $\mathrm{pH}$ observed during the

TABLE IV

Distribution of sodium in control and depleted rats

\begin{tabular}{|c|c|c|c|c|c|}
\hline & Ceatera & \multicolumn{2}{|c|}{ Dopleted } & & \\
\hline Total & 52.8 & 52.5 & 42.0 & 20.8 & 100 \\
\hline$D_{10}$ & 2.4 & 0.3 & 0.2 & 2.2 & 20 \\
\hline & 2.2 & 10.3 & 8.2 & 3.0 & 23 \\
\hline & 39.1 & 42.9 & 33.5 & 5.6 & 52 \\
\hline
\end{tabular}

conounted ste ata as Cothow et al. 


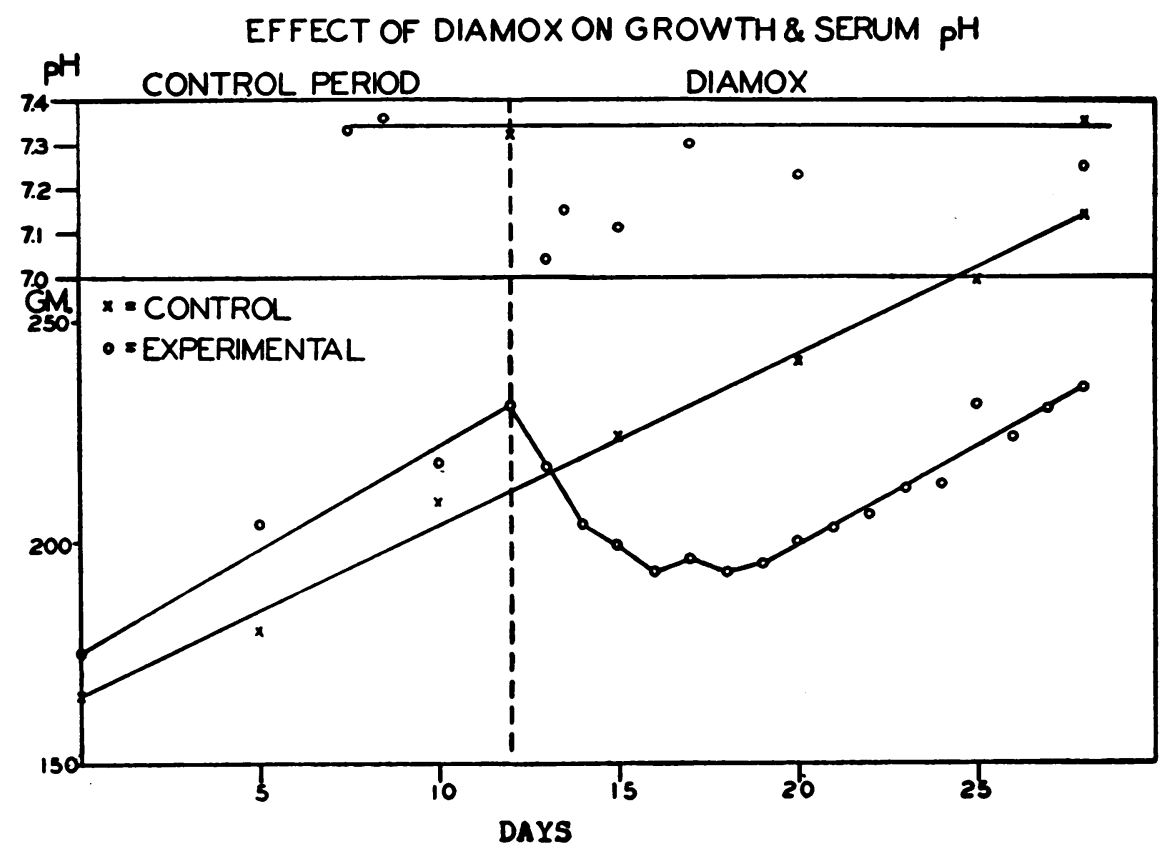

FIGURE 1

administration of acetazoleamide (Diamox $\left.{ }^{(}\right)$. After an initial weight loss, growth rate equalled that of the controls, although serum $\mathrm{pH}$ was depressed throughout the experimental period. Total body composition (Table II) did not differ significantly from that of control animals. Bone sodium to calcium ratio (Table III) was .0150 , or 71 per cent of the normal value of $.0206(\mathrm{p}=$ $.01)$.

\section{Acetazoleamide plus dialysis}

Dialysis of rats pre-treated with acetazoleamide for 13 days (Group 4) resulted in the removal of 29 per cent of calculated total body sodium content. Bone analysis after 48 hours showed a sodium to calcium ratio of .0174 as compared to .0163 for rats dialyzed without pre-treatment and .0150 for rats treated with acetazoleamide without dialysis. There was apparently no further loss of bone sodium following dialysis in rats whose bone sodium to calcium ratio had previously been reduced by acetazoleamide.

\section{Parenteral repair}

Table II shows the body composition of rats treated with parenteral sodium-containing fluid after dialysis. Total sodium was significantly in- creased ( $59 \mathrm{mEq}$. per $\mathrm{Kg}$.) over that found following dialysis and in normal controls. None of the sodium increment could be assigned to the skeletal phase, since bone sodium to calcium ratio was .0136. This is lower than the ratio found in depleted animals (.0163) but the difference is not statistically significant $(p=.05)$.

\section{Oral repair}

After five days of recovery on a normal diet, the rats in Group 6 had regained 86 per cent of their post-dialysis weight loss and were growing at the same rate as controls. Their bone composition (Table III) was not significantly different from that of Group 2 animals sacrificed immediately after depletion. There was apparently no sequestration of sodium in bone during the recovery period.

\section{DISCUSSION}

Intraperitoneal dialysis against ammonium chloride with subsequent removal of peritoneal fluid causes both sodium depletion and acidosis. Significant decreases in serum $\mathrm{pH}$ and $\mathrm{CO}_{2}$ content have been previously reported (8). Three phases contributed to the total sodium loss (Table IV) : 
A. Muscle cell water, which originally contained approximately 5 per cent of total body sodium, lost 20 per cent of the sodium removed by dialysis.

B. Extra bone sodium, comprising 21 per cent of normal total sodium content, contributed 28 per cent of the loss.

C. Extracellular sodium makes up 74 per cent of total body sodium in rats of the age used. Fifty-two per cent of the sodium loss was contributed by this phase.

The volume of distribution of extracellular sodium, $\left(\mathrm{H}_{2} \mathrm{O}_{\mathrm{Na}}\right)$, calculated as explained above, was $251 \mathrm{ml}$. per $\mathrm{Kg}$. of fat-free body weight in control rats and $274 \mathrm{ml}$. in dialyzed rats. Allowing for 20 per cent weight loss, the decrement in $\mathrm{H}_{2} \mathrm{O}_{\mathrm{Na}}$ was therefore $251-(.8 \times 274)=32$ $\mathrm{ml}$. per original $\mathrm{Kg}$.

If the entire sodium loss of $10.8 \mathrm{mEq}$. per $\mathrm{Kg}$. had been sustained by extracellular sodium, a decrease of approximately $60 \mathrm{ml}$. or 24 per cent would have been necessary to preserve normal sodium concentration in extracellular fluid following dialysis.

The volume of distribution of chloride $\left(\mathrm{H}_{2} \mathrm{O}_{\mathrm{cl}}\right.$, corrected for red cell and collagen water as explained above) is compared with $\mathrm{H}_{2} \mathrm{O}_{\mathrm{Na}}$ in Table II. $\mathrm{H}_{2} \mathrm{O}_{\mathrm{Cl}}$ exceeds $\mathrm{H}_{2} \mathrm{O}_{\mathrm{Na}}$ in both normal and dialyzed animals. Since the methods for estimating both phases are indirect and involve several steps (see "Calculations" above), no significance can be assigned to the difference. The discrepancy is greater in the dialyzed animals, which may be due to the fact that dialysis against ammonium chloride caused a greater loss of sodium than of chloride.

Weight loss (20 per cent) and sodium loss (21 per cent) were nearly identical after dialysis. This implies a proportionate reduction of body mass during the 48-hour post-dialysis fast. Since the composition of weight loss during fasting varies with the length of the fast, the close agreement between loss of sodium and loss of weight seen in these experiments must be coincidental.

Since both acidosis and sodium depletion followed dialysis, the relative importance of each in bone sodium mobilization is not indicated. The chemical relationship of sodium to the apatite crystal structure of bone has not been precisely defined. However, the data of Neuman and his associates afford a clue (19). Their studies indicate that bone carbonate may be linked to calcium by a single bond, the other carbonate valence being occupied by a monovalent cation such as sodium or potassium. In experiments performed by the present author (20), losses of bone sodium and potassium during acute acidosis in rats were compared to simultaneous changes in bone carbonate. The ratios calculated agreed with the hypothesis that sodium and potassium are present in bone as double salts of carbonate having the formula $\mathrm{Ca}-\mathrm{O}-\mathrm{COO}-\mathrm{Na}(\mathrm{K})$. Parallel increases in sodium and carbonate observed with ageing (8) are also consistent with the association suggested. It appears likely that such carbonate salts would be vulnerable to changes in $\mathrm{pH}$ of the surrounding extracellular fluid, and that sodium might be liberated during acidosis (as $\mathrm{NaHCO}_{3}$ ) whether there were net loss of sodium from the body or not.

The work with $\mathrm{Na}^{24}$ mentioned above (3-6) has shown that a fraction of bone sodium (approximately 30 per cent) is in equilibrium with circulating radiosodium. Rapid dialysis might cause a shift of this fraction by reducing the sodium concentration of extracellular fluid. However, exchangeable sodium is apparently entirely removed by peritoneal dialysis against ammonium chloride, while the sodium concentration of extracellular fluid is reduced slightly if at all $(8,10)$. This suggests that the concomitant acidosis may be of crucial importance in the mobilization of bone sodium.

The imposition of direct acid loads in the rat has had varying results. Irving and Chute (21) found a reduction in bone carbonate following acute oral $\mathrm{HCl}$ loads. Burns (22) reported that prolonged feeding of 0.1 normal $\mathrm{HCl}$ (12 to 100 ml. per rat per day) had no effect on bone carbonate. Neither of these studies included measurements of serum $\mathrm{pH}$. Ingalls, Donaldson, and Albright (23) observed demineralization of bone in nephrectomized rats given $\mathrm{HCl}$, but their report includes no chemical analyses.

Acetazoleamide, (Diamox ${ }^{(\mathbb{})}$ ), a substituted sulfonamide, is known to inhibit carbonic anhydrase activity. It increases urinary excretion of sodium and potassium, presumably by interfering with tubular exchange of hydrogen for other 
cations. Continuous administration results in return of the normal urinary electrolyte pattern with persistent depression of carbonic anhydrase activity and serum $\mathrm{pH}$ (24-26). The initial diuresis causes an average net sodium loss of $5 \mathrm{mEq}$. per $\mathrm{Kg}$. in the rat; sodium balance becomes positive within 24 to 48 hours (26). The decrease in bone sodium and sodium to calcium ratio found in Group 3 after acetazoleamide treatment was equal to that seen after dialysis (Table III), although the net sodium loss was much less ( 5 as compared to $10.8 \mathrm{mEq}$. per kilo). These results suggest that acidosis per se may be essential to the removal of bone sodium.

When acetazoleamide was followed by dialysis, no further decrease in bone sodium or sodium/ calcium ratio occurred. The remainder ( 71 per cent of the control value) was apparently not available to the total body sodium economy. The lability of 29 per cent of total extra bone sodium indicated here is in close agreement with previous findings discussed above.

The exchangeability of bone sodium with circulating radiosodium and its availability in acidosis and sodium depletion suggest the possibility of sequestration of this cation in bone during recovery from acidosis. Such storage would influence interpretation of sodium balance during treatment of diarrhea, diabetic acidosis, and other disorders involving electrolyte loss. Darrow (27) has shown that more sodium may be retained during therapy for diarrhea than can be accounted for by measured extracellular increments. Gamble and his associates have found similar results following sodium loads in normal infants (28). In the present study neither parenteral nor oral repair of depleted animals caused significant elevation of bone sodium (Table III). In the former instance an increment of total body sodium was measured; in the latter it was inferred from recovery of the weight lost during depletion (Table II). Apparently little or none of the sodium retention observed during recovery from acidosis can be assigned to the skeletal phase. It has been mentioned above that bone sodium is probably mobilized according to the equation $\mathrm{Ca}-\mathrm{O}-\mathrm{C}-$ $\mathrm{OO}-\mathrm{Na}+\mathrm{H}$-Anion $\rightarrow \mathrm{Ca}$-Anion $+\mathrm{NaHCO}_{3}$. The anion involved has not been identified. The composition of bone salt and body fluid both suggest phosphate as a possibility. If so, the calcium valences formerly occupied by $-\mathrm{O}-\mathrm{C}-\mathrm{OO}-\mathrm{Na}$ would no longer be available to sodium, and restitution of normal bone sodium content would be delayed until the surface of the apatite crystals of bone had undergone either growth or re-arrangement. This hypothesis may explain the oneway movement of bone sodium in relatively acute situations.

\section{SUMMARY AND CONCLUSIONS}

1. Sodium loss following intraperitoneal dialysis against ammonium chloride is shared by extracellular sodium ( 52 per cent), intracellular sodium (20 per cent) and bone sodium (28 per cent).

2. The production of acidosis without large or sustained sodium loss results in a decrement of bone sodium as great as that seen after sodium depletion.

3. Only 29 per cent of bone sodium content can be mobilized by any procedure studied thus far.

4. No sodium is deposited in the skeleton of the rat following either oral or parenteral repair of acidosis and sodium depletion within the period studied (five days).

\section{ACKNOWLEDGMENT}

The author is much indebted to Mrs. Ellen H. Bell for patient and skilful technical assistance.

\section{REFERENCES}

1. Gabriel, S., Chemische untersuchungen über die mineralstoffe der knochen und zähne. Ztschr. f. physiol. Chem., 1894, 18, 257.

2. Harrison, H. E., Darrow, D. C., and Yannet, H., The total electrolyte content of animals and its probable relation to the distribution of body water. J. Biol. Chem., 1936, 113, 515.

3. Kaltreider, N. L., Meneely, G. R., Allen, J. R., and Bale, W. F., Determination of the volume of the extracellular fluid of the body with radioactive sodium. J. Exper. Med., 1941, 74, 569.

4. Forbes, G. B., and Perley, A., Estimation of total body sodium by isotopic dilution. I. Studies on young adults. J. Clin. Invest., 1951, 30, 558.

5. Stern, T. N., Cole, V. V., Bass, A. C., and Overman, R. R., Dynamic aspects of sodium metabolism in experimental adrenal insufficiency using radioactive sodium. Am. J. Physiol., 1951, 164, 437.

6. Edelman, I. S., James, A. H., Baden, H., and Moore, F. D., Electrolyte composition of bone and the penetration of radiosodium and deuterium oxide 
into dog and human bone. J. Clin. Invest., 1954, $33,122$.

7. Nichols, G., Jr., and Nichols, N., The availability of bone sodium. Clin. Research Proc., 1953, 1, 91.

8. Bergstrom, W. H., and Wallace, W. M., Bone as a sodium and potassium reservoir. J. Clin. Invest., 1954, 33, 867.

9. Darrow, D. C., Schwartz, R., Iannucci, J. F., and Coville, F., The relation of serum bicarbonate concentration to muscle composition. J. Clin. Invest., 1948, 27, 198.

10. Cotlove, E., Holliday, M. A., Schwartz, R., and Wallace, W. M., Effects of electrolyte depletion and acid-base disturbance on muscle cations. Am. J. Physiol., 1951, 167, 665.

11. Wallace, W. M., Holliday, M., Cushman, M., and Elkinton, J. R., The application of the internal standard flame photometer to the analysis of biological material. J. Lab. \& Clin. Med., 1951, 37, 621.

12. Van Slyke, D. D., and Hiller, A., Application of Sendroy's iodometric chloride titration to proteincontaining fluids. J. Biol. Chem., 1947, 167, 107.

13. Hastings, A. B., and Sendroy, J., Jr., Studies of acidosis. XX. The colorimetric determination of blood $\mathrm{pH}$ at body temperature without buffer standards. J. Biol. Chem., 1924, 61, 695.

14. Schwartz, R., Cohen, J., and Wallace, W. M., Tissue electrolyte changes of the whole body, muscle, erythrocyte and plasma of rats on a potassium deficient diet. Am. J. Physiol., 1953, 172, 1.

15. Sunderman, F. W., and Williams, P., The analysis of chloride in tissues. J. Biol. Chem., 1933, 102, 279.

16. Nichols, G., Jr., Nichols, N., Weil, W. B., and Wallace, W. M., The direct measurement of the extracellular phase of tissues. J. Clin. Invest., 1953, 32, 1299.

17. Bernstein, R. E., Potassium and sodium balance in mammalian red cells. Science, 1954, 120, 459.
18. Lightfoot, L. H., and Coolidge, T. B., The distribution of collagen in the guinea pig. J. Biol. Chem., 1948, 176, 477.

19. Neuman, W. F., Neuman, M. W., Main, E. R., O'Leary, J., and Smith, F. A., The surface chemistry of bone. II. Fluoride deposition. J. Biol. Chem., 1950, 187, 655.

20. Bergstrom, W. H., The relationship of sodium and potassium to carbonate in bone. J. Biol. Chem., 1954, 206, 711.

21. Irving, L., and Chute, A. L., The participation of the carbonates of bone in the neutralization of ingested acid. J. Cell. \& Comp. Physiol., 1933, 2, 157.

22. Burns, C. M., The effect of the continued ingestion of mineral acid on growth of body and bone and on the composition of bone and of the soft tissue. Biochem. J., 1929, 23, 860.

23. Ingalls, T. H., Donaldson, G., and Albright, F., The locus of action of the parathyroid hormone: Experimental studies with parathyroid extract on normal and nephrectomized rats. J. Clin. Invest., 1943, 22, 603.

24. Maren, T. H., and Wadsworth, B. C., Blocking of renal effect of Diamox(b) 2-acetylamino-1,3,4-thiadiazole-5-sulfonamide, by metabolic acidosis. Federation Proc., 1954, 13, 383.

25. Bergstrom, W. H., Garzoli, R. F., Lombroso, C., Davidson, D. T., and Wallace, W. M., Observations on the metabolic and clinical effects of carbonic-anhydrase inhibitors in epileptics. Am. J. Dis. Child., 1952, 84, 771.

26. Walton, R. L., Spiro, R. H., and Bergstrom, W. H., To be published.

27. Darrow, D. C., The retention of electrolyte during recovery from severe dehydration due to diarrhea. J. Pediat., 1946, 28, 515.

28. Gamble, J. L., Wallace, W. M., Eliel, L., Holliday, M. A., Cushman, M., Appleton, J., Shenberg, A., and Piotti, J., Effects of large loads of electrolytes. Pediatrics, 1951, 7, 305. 